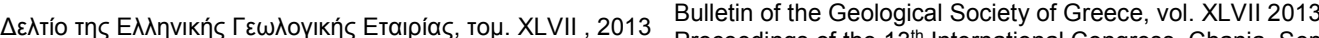

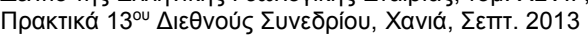

\title{
INVESTIGATING THE EXISTENCE OF A "PALAEO-FORESHORE" ZONE AT MOLOS BEACH (KEFALOS BAY, PAROS, GREECE)
}

\author{
Poulos S. ${ }^{1}$, Ghionis G. ${ }^{1}$ and Petrakis S. ${ }^{1}$ \\ ${ }^{I}$ National and Kapodistrian University of Athens, Faculty of Geology and Geoenvironment, \\ Department of Geography-Climatology, Panepistimioupoli, Zografou 157 84, Athens, Greece, \\ poulos@geol.uoa.gr,gghionis@geol.uoa.gr,spetrakis@geol.uoa.gr
}

\begin{abstract}
The present study investigates the existence of a "palaeo-foreshore zone" at Molos beach in or after 1884 A.D., as defined in the Greek legislation (Law 2971/ 19.12.2001). To this end, existing geological and climatological information were gathered, detailed geomorphological mapping was carried out and surficial sediment samples were collected along a shore-normal transect extending from the backshore to the nearshore (subaqueous) zone. In addition, sedimentological /stratigraphical data were obtained from two trenches $(1.5 \mathrm{~m}$ and $3 \mathrm{~m}$ deep) that were excavated on the landward side of the coastal dunes. Topographic maps, aerial photographs and satellite images are used to study the recent changes of the shoreline position. On the basis of the above, it is concluded that the current backshore zone has recently evolved from a shallow lagoonal, to a terrestrial environment. The submerged beach rock formations are at similar water depths (0.3-0.4 m) with those observed in other islands of the Cyclades complex (i.e. Rhenia, Naxos) whose formation has been radio-carbon dated at least 200 years BP, indicating that the 1884 A.D. shoreline was not landward, but approximately $15 \mathrm{~m}$ offshore relative to its present position
\end{abstract}

Key words: Pocket beach, submerged coastline, beach-rock.

\section{Пєрі́⿱亠乂 $\psi \eta$}

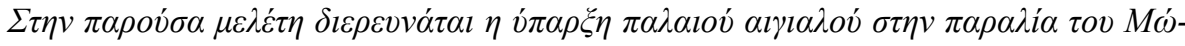

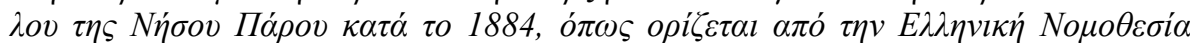

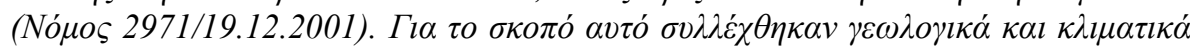

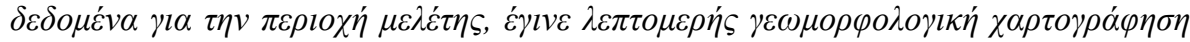

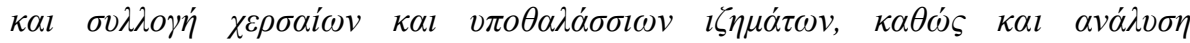

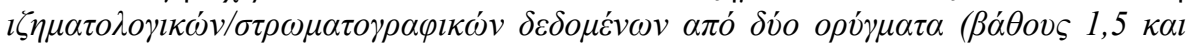

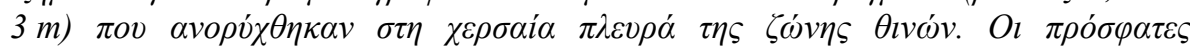

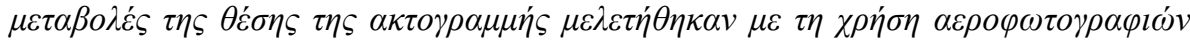

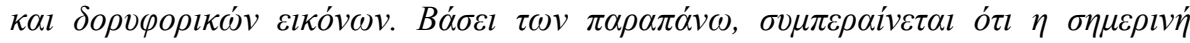

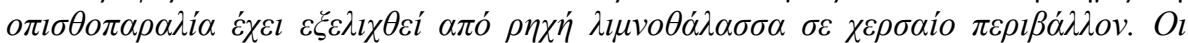

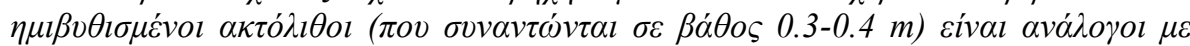

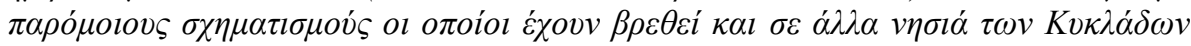

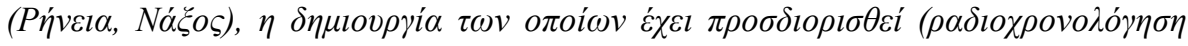




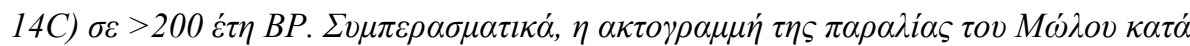

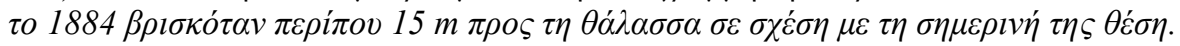

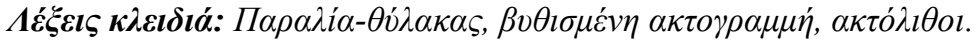

\section{Introduction}

According to Greek Legislation (Law 2971/19.12.2001), the Greek State does not recognize private property which is located today seaward of the coastline position of 1884 A.D. Due to the lack of accurate topographic maps before 1900, the determination of the 1884 shoreline position can be achieved only through the study of the geological/geomorphological evolution of each individual stretch of coast over the past centuries. Such studies have been carried out for a number of Greek coastal zones (e.g. by Pehlivanoglou and Papathanasoglou (2004) for the coastal front of the city of Heraklion, Crete).

The present investigation examines the existence of a "palaeo-foreshore zone" at Molos Beach of Paros Island, with reference to the year 1884 A.D., based on the evolution of the backshore zone, its morphological and sedimentological characteristics and published information.

\section{Study Area}

Molos beach is located in Kefalos Bay of Paros Island in the Aegean Sea, Greece between Antikefalos cape (North) and Kratzi cape (South) (Figure 1). Its coastline is $1 \mathrm{~km}$ long, with N-S orientation. Geologically it belongs to the Attico-cycladic geotectonic zone, which is characterized by light seismicity and the presence of metamorphic rocks. The coastal plain landward of the beach consists of Quaternary alluvial deposits, which lie on top of the "Marmara" metamorphic unit. Molos Beach is a pocket-beach (see Figure 1), with beach rock formations visible at its central and southern parts. Landward of the beach, there is a dune field with dunes up to $2.5 \mathrm{~m}$ high, which have been partially destroyed by the construction of a coastal road and other anthropogenic interventions (agriculture, buildings, etc.). At the southern part of the beach, the dune field is wider $(60-70 \mathrm{~m})$ with most of its surface covered by perennial trees. The study is focused at the central and southern part of the beach, since its northern part hasn't been significantly affected over the years.

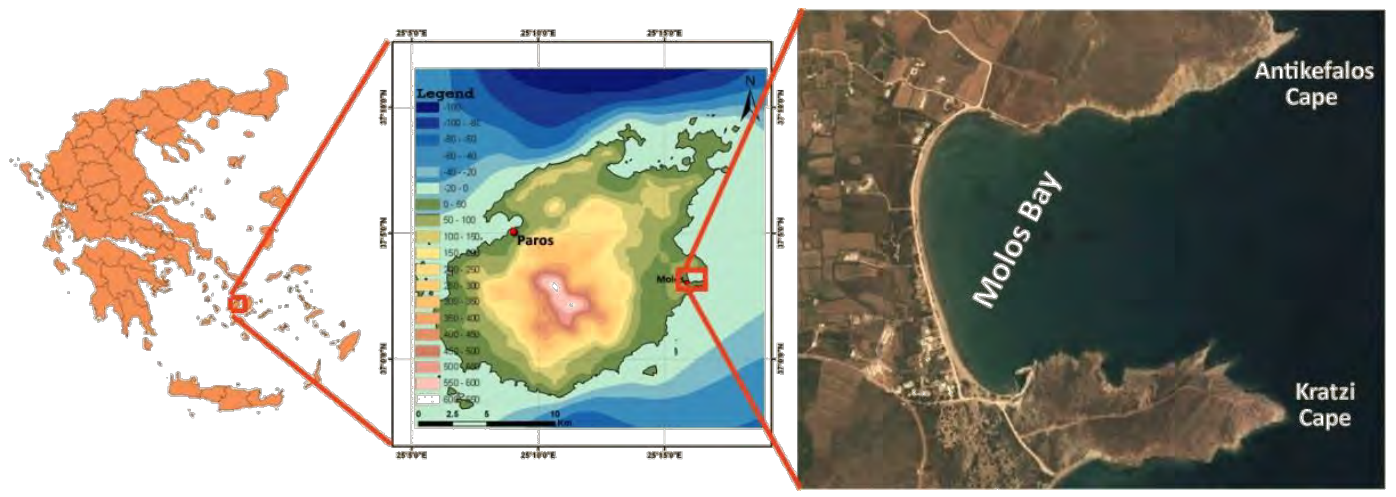

Figure 1 - Location of the study area.

At the central and northern parts of the beach zone, the dunes are absent, and there is a large abandoned agricultural field, which is flooded sporadically by the main torrent that debouches at the northern end of Molos beach. The associated agricultural coastal plain, consisting of Holocene alluvial deposits is characterized by small slopes $(<5 \%)$. These, in association to the low rainfall levels, indicate a limited sediment influx to the shore. 
On the contrary, the northern and southern parts of Kefalos Bay have high slopes (25-30\%) and consist of highly erodible lithology (alluvial deposits, molasses, schists) representing, most probably, the main source of beach sediment. The presence of a large number of wells indicates a surficial aquifer of fresh or slightly brackish water.

The $\mathrm{N}$ and NE winds are dominant in the broader area, with an annual frequency exceeding 50\% (Poulos et. al., 2012). In Kefalos Bay, the dominant winds are from the E, with annual frequency of $1.12 \%$. The most frequent wind speed is 13 knots, with an annual frequency of $18.72 \%$. Maximum wind speed is associated with $\mathrm{E}$ winds up to $55 \mathrm{knots}$, having an annual frequency of $0.01 \%$.

Molos beach is affected mainly by wind-generated waves of $\mathrm{E}$ origin. Their maximum wave heights $\left(\mathrm{H}_{\max }\right)$ and periods $\left(\mathrm{T}_{\max }\right)$ are $1.43 \mathrm{~m}$ and $4 \mathrm{~s}$, respectively, occurring during March, with a mean annual frequency of occurrence about $0.1 \%$ (Poulos et al., 2012). NE and SE wind-generated waves affect the beach (mainly the southern and northern ends of the beach, respectively) only after diffraction and refraction and are associated, therefore, with reduced wave energy and weak nearshore currents (Poulos et al., 2012).

The rate of sea level rise in the study area does not exceed $1 \mathrm{~mm} /$ year, as shown by Poulos et al. (2009) and Pavlopoulos et al. (2010).

Regarding the human intervention, Molos Beach is characterized by: (i) the construction of a small fishing shelter at the southern end of the beach; (ii) the construction of a coastal road along the beach and on top of the seaward side of the dune field and (iii) the removal of beach sediment during the cleaning of the beach face from seaweeds at the beginning of each touristic season..

\section{Materials and Methods}

The coastal stratigraphy in the area of the dune field was studied through the analysis of 15 sediment samples obtained from two trenches (1.5 and $3.5 \mathrm{~m}$ deep), which were excavated at a distance of $70 \mathrm{~m}$ (Trench 1) and $77 \mathrm{~m}$ (Trench 2) from the coastline (Figure 2). The foraminifera and gastropods contained in the samples were identified and classified with respect to their habitat.

Coastline displacement was investigated through the extraction and intercomparison of shoreline positions from aerial photographs taken in 1945, 1960 and 1997 and two satellite images of 2005 and 2010, in a GIS platform.

One water sample was collected from Trench 2 at a depth of $1.5 \mathrm{~m}(0.2 \mathrm{~m}$ above mean sea level), while a second water sample was collected from an existing well (Figure 2), $1 \mathrm{~m}$ above mean sea level. Both water samples were analyzed in the Laboratory of Environmental Chemistry and their conductivity and $\mathrm{pH}$ were determined.

To study the morphology of the coastal zone, a shore-normal topographic profile was measured in the central part of the beach, from the trench area in the dune field to a water depth of $4 \mathrm{~m}$. Eight surficial sediment samples were collected along this profile and were analyzed and classified according to Folk (1974) (Figure 2).

The subsurface lateral extent of the observed beach rock formations together with the thickness of the beach material covering them, were investigated with the use of a hand-driven, $6 \mathrm{~mm}$ in diameter, penetration rod. Probing every $5 \mathrm{~m}$ along beach and along the shore-normal profile, the existence of a subsurface beach rock formation (below a few centimeters to a few tens of centimeters of sandy sediments) was accurately mapped and is shown in Figure 2 (red dots)

$\underline{\text { XLVII, No } 3-1574}$ 


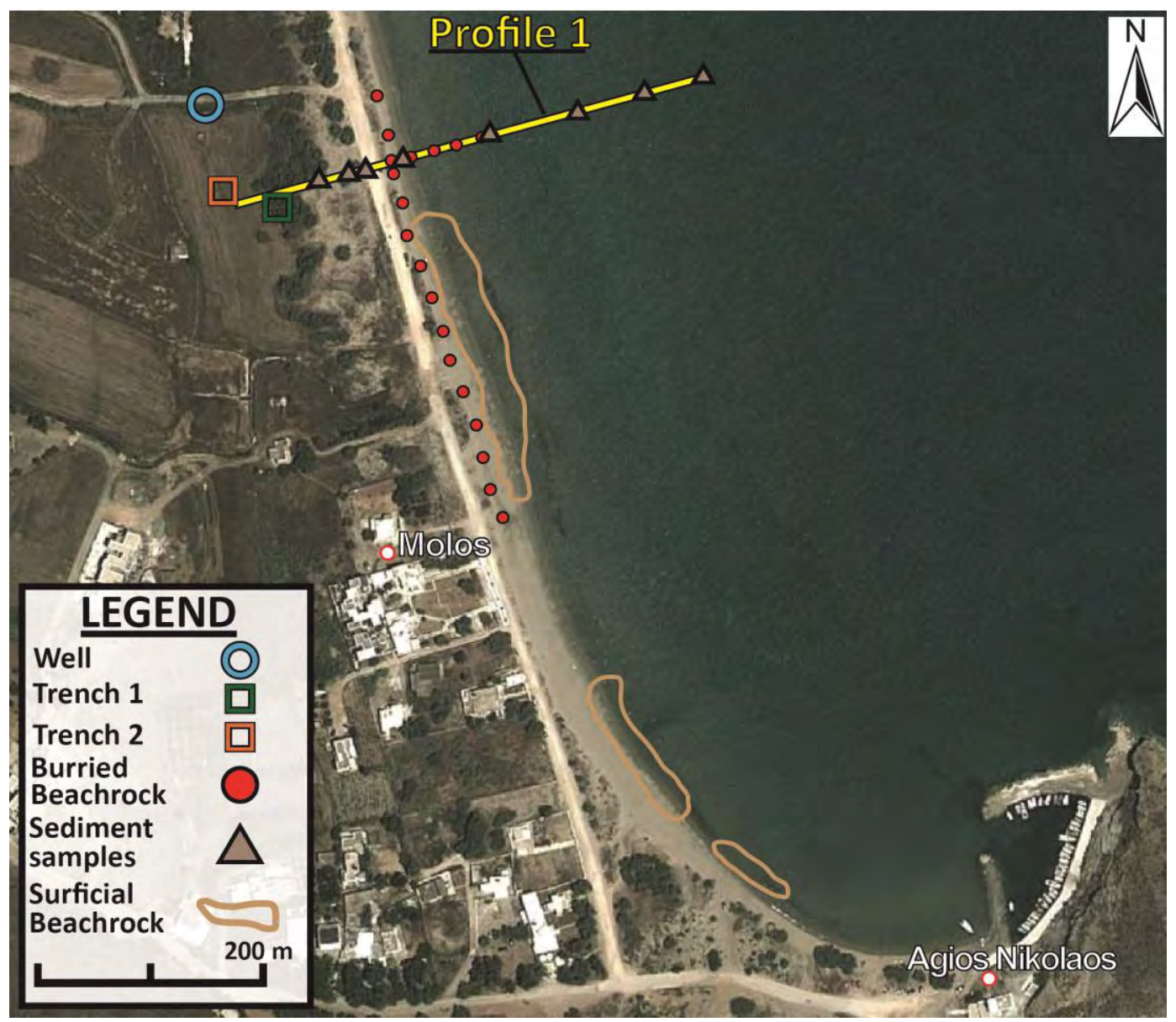

Figure 2 - Aerial photograph of the southern half of Molos Bay, showing the shore-normal profile, the two excavated trenches, the sediment sampling locations and the surficial beach rock formations.

\section{Results and Discussion}

The subaerial part of the beach has an average width of $20 \mathrm{~m}$ (from the shoreline to the foot of the dunes) and it is characterised by low slopes.

In the subaqueous part of Profile 1 , the seabed slopes gradually up to the depth of $4 \mathrm{~m}$. At a distance of 50-80 $\mathrm{m}$ from the coastline, at a water depth of approximately $1 \mathrm{~m}$, a short $(0.5 \mathrm{~m} \mathrm{high})$ bar is present, indicating the location of a breaking zone (Figure 3 ).

The dune field, the subaqueous bar and the seabed at depths greater than $4 \mathrm{~m}$ consist of sand (S), whilst the remaining parts consist of relatively coarser material (i.e. slightly gravelly sand $(\mathrm{g}) \mathrm{S})$.

The first beach rock formation (closer to the coastline) is visible about $15 \mathrm{~m}$ seaward of the coastline and has a width of up to $10 \mathrm{~m}$, extending to a water depth of 0.4 to $0.8 \mathrm{~m}$ (Figure 3 ). Penetration tests showed that beach rocks are present all along the beach face under a $10-20 \mathrm{~cm}$ thick sandy layer, extending to approximately $10 \mathrm{~m}$ landward of the shoreline. Beach rocks are not present in the upper part of the beach (close to the dunes), however at a depth of 0.5-0.7 m a gravelly layer ( $\sim 5 \mathrm{~cm}$ diameter) is found. There are no surficial beach rock formations and no buried beach rocks have been detected in the northern part of the beach. This absence of beach rocks may be related to the discharge of an intermittent stream in the area. 
The second beach rock formation, found at a distance of about $25 \mathrm{~m}$ from the coastline, has also a width of $10 \mathrm{~m}$ and lies between 0.6 and $1 \mathrm{~m}$ below mean sea level.

At about $0.5 \mathrm{~m}$ below sea level, the two beach rock groups merge, creating an underwater step.

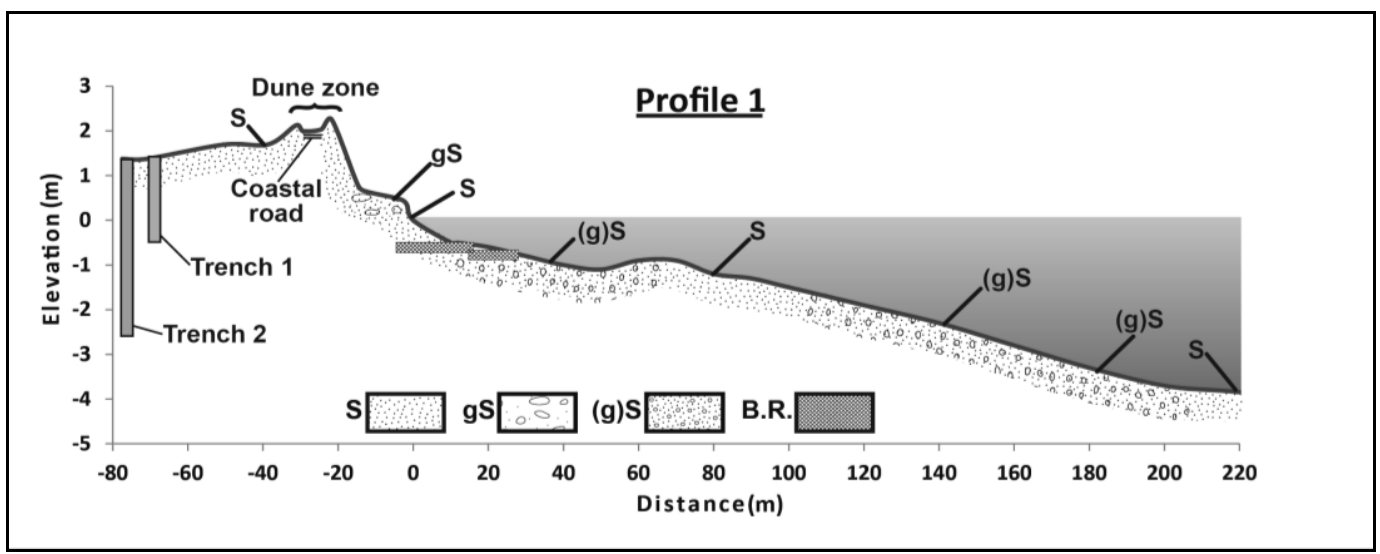

Figure 3 - Topographic profile of the Molos coastal zone showing the locations of the two trenches, the surficial sediment samples and the beach rock formations (B.R.) along with the granulometric characterisation of the surficial sediments (S: sand; gS: gravelly sand; (g)S: slightly gravelly sand).

Based on radiocarbon dating, beach rock formations in the Cycladic islands (Paros, Naxos) indicate the existence of submerged old coastlines $35 \pm 5 \mathrm{~cm}$ below present sea level, 232 years B.P. (Evelpidou et al., 2009 and 2012). On the basis of these observations, the shallower beach rocks (water depths 40-75 cm) found in Molos beach could not be formed later than 200 years B.P.. The sedimentological and lithostratigraphic analyses of the sediment samples collected from the two trenches (Figure 4) have shown that the surficial layer in both trenches is about $50 \mathrm{~cm}$ thick and consists of gravelly sand (Trench 1) and muddy sand (Trench 2); it is a mixture of aeolian sands and fluvial deposits, reworked by agriculture.

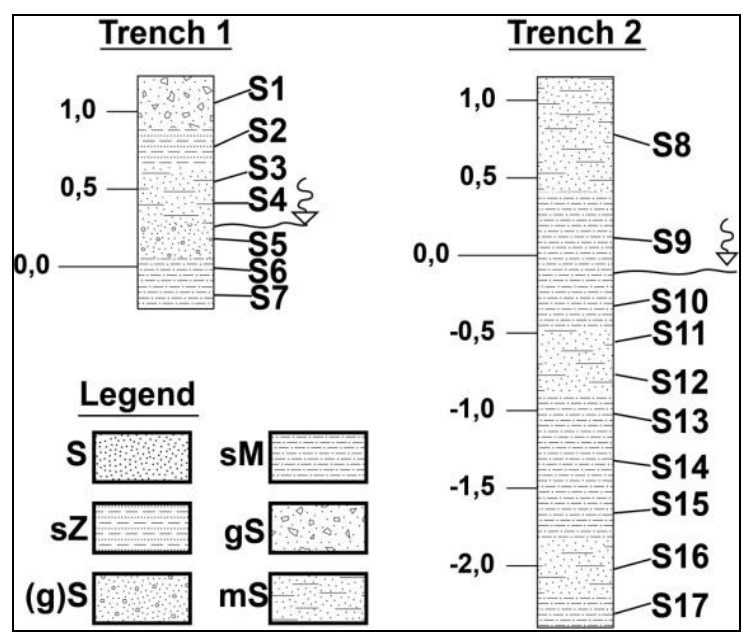

Figure 4 - Stratigraphic columns from the two trenches. Elevations relative to mean sea level are indicated on the left side of the columns and sediment sample levels are indicated on the right side. The arrows indicate the level of the groundwater table. (S): sand, (sM): sandy mud, (sZ): sandy silt, (gS): gravelly sand, ((g)S): slightly gravelly sand, (mS): muddy sand. 
Beneath the top layer, the material becomes finer (i.e. sandy silt (sZ) - Trench 1 (for $0.5 \mathrm{~m}$ ) and sandy mud (sM) - Trench-2 (for $1 \mathrm{~m}$ ). Based on their position $(>0.5 \mathrm{~m}$ above mean sea level), their macroscopic appearance and their texture (very fine grains), it is concluded that the sediments of this layer are of terrestrial (or lagoonal) origin. This is because the geology and the hydrodynamic regime of Molos bay preclude the deposition of silty and muddy sediments in the coastal zone (Poulos et al., 2012). Farther down in Trench 1, the silty layer is followed by a muddy and slightly gravelly sandy layer $(0.7 \mathrm{~m}$ thick $)$ and finally by a muddy layer. These layer successions indicate a lagoonal deposition environment, with a periodical feeding of coarser-grained torrential material.

In Trench 2, the muddy layer is interrupted by the presence of thinner layers of brownish muddy sand.

The various species of foraminifera and gastropods identified in the Trench-2 samples, together with their deposition environments, are given in Table 1.

Table 1 - Foraminifera species analysis.

\begin{tabular}{|c|c|c|c|c|}
\hline Sample No & $\begin{array}{l}\text { Sample depth } \\
\text { below m.s.l. (m) }\end{array}$ & \multicolumn{2}{|c|}{ Foraminifera species } & Environment \\
\hline 10 & 0.5 & \multicolumn{2}{|l|}{ - } & Terrestrial \\
\hline 13 & 1 & $\begin{array}{l}\text { - Quinqueloculina sp. } \\
\text { - Cibicides } \\
\text { - Elphidium }\end{array}$ & $\begin{array}{l}\text { - Oridorsalis } \\
\text { - Ammonia } \\
\text { - Gyroidina }\end{array}$ & $\begin{array}{c}\text { Marine } \\
\text { (shallow) - } \\
\text { brackish }\end{array}$ \\
\hline 14 & 1.3 & \multicolumn{2}{|l|}{-} & Terrestrial \\
\hline 15 & 1.5 & $\begin{array}{l}\text { - Elphidium } \\
\text { - Rosalina globularis } \\
\text { - Ammonia }\end{array}$ & $\begin{array}{l}\text { - Quinqueloculina } \\
\text { - Oridorsalis }\end{array}$ & $\begin{array}{l}\text { Marine } \\
\text { (shallow) - } \\
\text { brackish }\end{array}$ \\
\hline
\end{tabular}

The first half meter below mean sea-level (sample 10) is characterised by the absence of foraminifera (Table 1). Its brownish colour, indicates a terrestrial deposition environment. On the other hand, the foraminifera found in samples 13, 14 and 15 (1-1.5 m below the upper layer) indicate a shallow marine to terrestrial deposition environment. Concerning the Gastropods (Table 2 ), the first $0.5 \mathrm{~m}$ below mean sea level is characterized by the presence of land snails (Helicidae)

Table 2 - Gastropod species analysis.

\begin{tabular}{|c|c|c|c|c|c|}
\hline $\begin{array}{c}\text { Sample } \\
\text { No }\end{array}$ & $\begin{array}{c}\text { Sample depth } \\
\text { below m.s.l. (m) }\end{array}$ & \multicolumn{3}{|c|}{ Gastropod species } & Environment \\
\hline 10 & 0.5 & - Helicidae & \multicolumn{2}{|c|}{-Hydrobia sp. } & Terrestrial \\
\hline 13 & 1 & $\begin{array}{l}\text { - Hydrobia sp. } \\
\text { - Barleeia sp } \\
\text {-Helicidae }\end{array}$ & \multicolumn{2}{|c|}{$\begin{array}{l}\text { - Myosotella myositis } \\
\text { - Truncatella subcylindrica }\end{array}$} & $\begin{array}{l}\text { Fresh - } \\
\text { brackish }\end{array}$ \\
\hline 14 & 1.3 & \multicolumn{3}{|c|}{$\begin{array}{l}\text { - Truncatella subcylindrica } \\
\text { - Myosotella myosotis }\end{array}$} & $\begin{array}{l}\text { Terrestrial - } \\
\text { brackish }\end{array}$ \\
\hline 15 & 1.5 & $\begin{array}{l}\text { - Truncatella } \\
\text { lindrica } \\
\text { - Hydrobia act }\end{array}$ & $\begin{array}{l}\text { subcy- } \\
\text { ita }\end{array}$ & $\begin{array}{l}\text { - Myosotella myositis } \\
\text { - Rissoidae Trochidae }\end{array}$ & $\begin{array}{c}\text { Marine } \\
\text { (shallow) - } \\
\text { brackish }\end{array}$ \\
\hline
\end{tabular}


and a few Hydrobia species, indicating rather a terrestrial deposition environment. In sample 13 the presence of land snails is significantly decreased and the fresh - brackish water gastropod Hydrobia sp. (Reizopoulou \& Nicolaidou, 2004; Pavlopoulos et al., 2010) is abundant, accompanied by few specimens of Truncatella subcylindrica and Myosotella myosotis. T. subcylindrica lives high on the shore, under stones, wood and plants, in places occasionally wetted by seawater (Poppe \& Goto, 1991) and M. myosotis is common in marshes and among rolled stones above the supratidal level (Martins, 1999). In sample 14 abundance of the gastropod Truncatella subcylindrica is observed along with Myosotella myosotis. Finally in sample 15 few specimens are present and belong to the species Hydrobia acuta, Truncatella subcylindrica and Myosotella myosotis. Hydrobia acuta inhabits brackish and saline coastal lagoons and also occurs in the littoral zone (Britton, 1985).

Thus, this backshore zone represents a transitional area from a rather shallow marine to lagoonal (with some terrestrial influxes) to finally terrestrial environment, covered by the aeolian sands of the present-day dunes.

The results of the chemical analysis of the water samples collected from the backshore zone (Figure 2) indicate a low degree of salinization of the coastal aquifer (Table 3). Considering that the water samples were collected in July, the increased salinity of the well is attributed to the intense evaporation of the stagnant water of the open well during the summer period. Hence, no intrusion of sea water was detected, a result that is attributed to the high groundwater table and the clayey character of the top layers of the terrestrial deposits.

Table 3 - Chemical analysis of the water samples.

\begin{tabular}{|c|c|c|c|}
\hline & Salinity (ppt) & $\begin{array}{c}\text { Conductivity } \\
(\boldsymbol{\mu S i e m e n s / c m )})\end{array}$ & $\mathbf{p H}$ \\
\hline Trench 2 & 8.1 & 13.8 & 7.7 \\
\hline Well & 32.9 & 50.1 & 7.2 \\
\hline
\end{tabular}

From the comparison of satellite images and aerial photographs (Figure 5), the northern and central parts of Molos Beach seem to have remained rather stable between 1945 and 2010 (shoreline displacements $<5 \mathrm{~m}$ ). At the southern part of the beach, a continuous shoreline retreat is observed from 1945 to 2005 ( $\sim 20 \mathrm{~m})$, followed by a slight progradation between 2005 and 2010 $(\sim 5 \mathrm{~m})$. An exception to this trend is the area close to the fishing shelter at the southern end of the beach, where the shoreline remains stable from 1945 to at least 1960, shows significant progradation in 1997 and $2005(\sim 20 \mathrm{~m})$ and then retreats to the 1960 position in 2010. The latter shoreline changes are most probably of anthropogenic origin and associated with the construction and maintenance of the fishing shelter.

\section{Conclusions}

Based on the above-mentioned geomorphological, sedimentological and stratigraphic findings, it is concluded that after the phase of rapid sea level rise that followed the last glacial period, and most probably during the last 4000 years, a barrier beach was formed in the coastal zone of Molos, which separated the alluvial plain (terrestrial environment) from Kefalos Bay (marine environment). A shallow lagoon with intermittent connection to the sea was formed landward of the barrier beach. Sediments of terrestrial (fluvial) origin were deposited in the lagoon when the inlets were closed, whilst beach sediments and shallow marine fauna were transported into the lagoon by the local hydrodynamic processes and deposited close to the barrier beach, mixed with terrestrial sediments, when the inlets were open (e.g. after significant storms). 


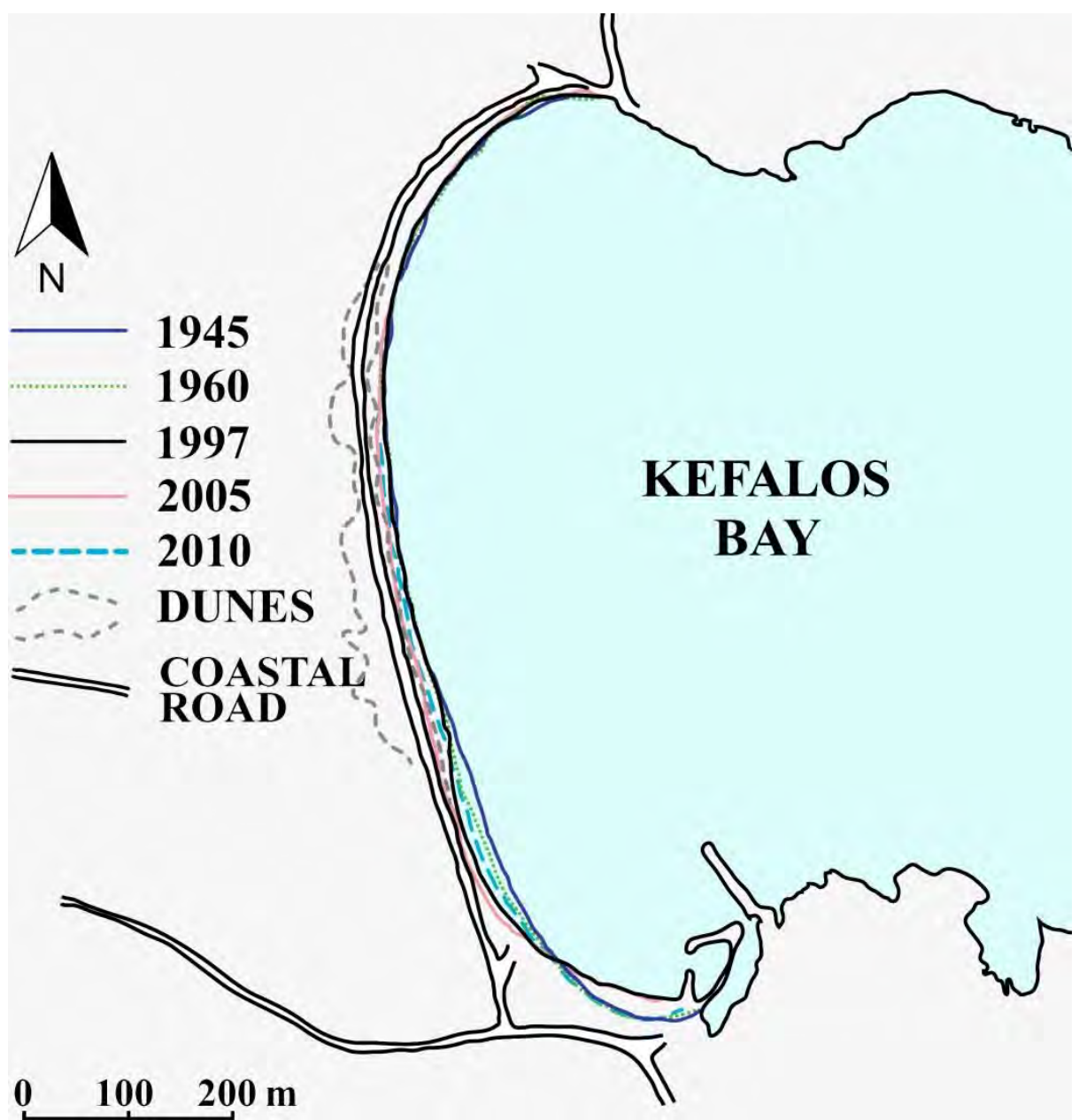

Figure 5 - Changes of the shoreline position of Molos Beach between 1945 and 2010, based on aerial photographs and satellite images.

Taking into account the rate of sea level rise $(\sim 1 \mathrm{~mm} /$ year) during the upper Holocene (Poulos et al., 2009) and the elevation of the lagoonal deposits with respect to the present sea level, the formation of the lagoon could go back to 1000 years BP.

The two beach rock formations at water depths of 0.4 and $1 \mathrm{~m}$ are evidence of old shorelines which are now submerged. The fact that the younger beach rock formation (at $0.4 \mathrm{~m}$ depth) has been dated in nearby islands at 232 years BP leads to the conclusion that 232 years ago the shoreline was located approximately $15 \mathrm{~m}$ seaward of its current position.

The comparative study of topographic maps, aerial photographs and satellite images showed that during the last 67 years there was no shoreline progradation. On the contrary, the shoreline of the north and central part of the beach remained stable, whilst the shoreline of the southern part has retreated.

On the basis of the above, it is concluded that during at least the last 300years (taking into account the time needed for the formation of the younger submerged beach rocks) the shoreline of Molos has not prograded and therefore the present-day backshore of Molos Beach (including the dune field) was not a "palaeo-foreshore zone", according to the Greek legislation, as the shoreline of 1884 A.D. is currently submerged. 


\section{Acknowledgments}

The authors would like to thank Mr. S. Stellas for the partial funding of this work through the 70/4/11778 research grant of the Special Account for Research Grants of the National and Kapodistrian University of Athens, Assoc. Prof. A. Antonarakou for her assistance in identifying the foraminifera and Phd Student Ch. Giamali for the assistance in identifying the gastropod species.

\section{References}

Britton R.H. 1985. Life cycle and production of Hydrobia acuta Drap. (Gastropoda : Prosobranchia) in a hypersaline coastal lagoon. Hydrobiologia, 122: 219-230.

Evelpidou N., Poulo, S.E. and Vassilopoulos A. 2009. Paros Island (Cyclades, Aegean Sea) Coastal Zone: Natural Processes and Dynamics. In D.R. Green (ed.), Coastal and Marine Geospatial Technologies, Springer, London, pp.285-296.

Evelpido, N., Pavlopoulos K., Vassilopoulos A., Triantafyllou M., Vouvalidis K. and Syrides G. 2012. Holocene palaeogeographical reconstruction of the western part of Naxos Island (Greece). Quaternary International, 266, 81-93

Folk P.L. (1974): Petrology of Sedimentary Rocks, Hemphill Publishing Co, Austin, Texas, 183 pp.

Martins A. M. F., 1999. On the generic separation of Ovatella Bivona, 1832 and Myosotella Monterosato, 1906 (Pulmonata, Ellobiidae). Iberus 17: 59-75

Pavlopoulos K., Triantaphyllou M., Karkanas P., Kouli K., Syrides G., Vouvalidis K., Palyvos N. and Tsourou Th. 2010. «Paleoenvironmental evolution and prehistoric human environment, in the embayment of Palamari (Skyros Island, Greece) during Middle-Late Holocene", Quaternary International, v.216, pp. 41-53.

Pehlivanoglou K. and Papathanasoglou A. 2004. Geologic and oceanographic data determining the "old foreshore zone", of the Heraklion coastal area, Crete Island. Global nest: the int. J., Vol 6, no 2, pp 157-166

Poppe G.T. and Goto Y. 1991. European Seashells. Vol. I, Polyplacophora, Caudofoveata, Solenogastra, Gastropoda. Verlag Christa Hemmen, Wiesbaden, pp. 1-352.

Poulos S.E., Ghionis G. and Maroukian H. 2009. Sea-level rise trends in the Attico-Cycladic region (Aegean Sea) during the last 5000 years. Geomorphology, 107(1-2), 10-17.

Poulos S.E., Ghionis G. and Petrakis S. 2012. Geologic / geomorphologic study of the coastal zone of Molos (Paros Isl.), with emphasis to the investigation of the existence of a "palaeoforeshore zone". Technical report, National and Kapodistrian University of Athens.

Reizopoulou S, Nicolaidou A. 2004. Benthic diversity of coastal brackish-water lagoons in western Greece. Aquatic Conservation: Marine and Freshwater Ecosystems 14: 93-102. 